\title{
Drug Hypersensitivity Quality of Life Questionnaire: validation procedures and first results of the Portuguese version
}

\author{
E. Dias de Castro ${ }^{1,2^{*}}$ (D) J. Barbosa ${ }^{3,4}$, A. M. Mesquita ${ }^{1}$, A. Caires ${ }^{1}$, L. Ribeiro ${ }^{3,5,6}$, J. R. Cernadas ${ }^{1}$ and I. Baiardini ${ }^{7}$
}

\begin{abstract}
Background: Hypersensitivity reactions to drugs are unpredictable and can be very complex and severe, even life threatening. Assess its impact on patient's health related quality of life (HRQoL) is crucial. The Drug Hypersensitivity Quality of Life Questionnaire (DrHy-Q) is the only validated disease-specific HRQoL questionnaire. We aimed to translate and cross-cultural validate the DrHy-Q to the Portuguese population. It was also our purpose to determine the impact of drug hypersensitivity on patients' HRQoL.

Methods: The translation and cross-cultural adaptation of the DrHy-Q to Portuguese was performed according to standards. Reliability of the DrHy-Q Portuguese version was assessed in terms of internal consistency and testretest reliability. Structural validity, divergent validity (with a generic health related QoLQ-PGWBI) and discriminant validity were also evaluated. Forty patients accepted to participate in the validation phase. The Portuguese version of the DrHy-Q was applied to 260 consecutively adult patients, studied in our Department for suspected drug hypersensitivity.
\end{abstract}

Results: The Portuguese DrHy-Q showed adequate internal consistency (Cronbach's a =0.938), good test-retest reliability [ICC $=0.713(95 \% \mathrm{Cl} 0.488-0.850]$ and one-dimensional structure. No significant correlation was found between the DrHy-Q and the PGWBI total scores $(r=-0.010, p=0.957)$. Two hundred of patients completed the study: 78.5\% female; mean age $=44 \pm 15$ years. Mean DrHy-Q score was $36.8 \pm 12.6$. Two clinical factors significantly predict DrHy-Q total score: clinical manifestations and number of suspected drugs. Patients with anaphylaxis $(\beta=11.005 ; 95 \% \mathrm{Cl} 5.523 ; 16.487)$, urticaria/angioedema $(\beta=7.770 ; 95 \% \mathrm{Cl} 2.600 ; 12.940)$ and other manifestations $(\beta=7.948 ; 95 \% \mathrm{Cl} 1.933 ; 13.962)$ are more likely to have higher DrHy-Q total score than patients with maculopapular exanthema. Patients with $\geq 2$ suspected drugs are also more likely to have worse $\mathrm{QoL}(\beta=7.927 ; 95 \% \mathrm{Cl} 3.687 ; 12.166$ ).

Conclusion: The Portuguese version of DrHy-Q revealed adequate validity and reliability, indicating that it is appropriate to assess the impact of drug hypersensitivity on patients' HRQoL, providing data for a better comprehension and management of our patients. Moreover, our results highlight that the severity of the drug hypersensitivity reaction and the number of suspected drugs have impact on patient's DrHy-QoL.

*Correspondence: eunicediascastro@gmail.com

${ }^{1}$ Allergy and Clinical Immunology Department, Centro Hospitalar Universitário de S. João EPE, Porto, Portugal

Full list of author information is available at the end of the article

\section{Background}

Drug allergic reactions are adverse drug reactions mediated by immunological mechanisms. They are unpredictable and potentially severe, even life-threatening. In practice, when an immunological mechanism cannot be demonstrated, the term drug hypersensitivity is applied to adverse drug reactions that clinically resemble allergy. original author(s) and the source, provide a link to the Creative Commons licence, and indicate if changes were made. The images or other third party material in this article are included in the article's Creative Commons licence, unless indicated otherwise in a credit line to the material. If material is not included in the article's Creative Commons licence and your intended use is not permitted by statutory regulation or exceeds the permitted use, you will need to obtain permission directly from the copyright holder. To view a copy of this licence, visit http://creativecommons.org/licenses/by/4.0/. The Creative Commons Public Domain Dedication waiver (http://creativeco mmons.org/publicdomain/zero/1.0/) applies to the data made available in this article, unless otherwise stated in a credit line to the data. 
Drug hypersensitivity reactions (DHR) comprise $15 \%$ of all adverse drug reactions [1-3] and are responsible for significant morbidity and socio-economical costs [4]. Due to their unpredictable nature and potential severity, drug hypersensitivity may have an important impact on patients' health-related quality of life (HRQoL). HRQoL is a central patient reported outcome defined as those aspects of self-perceived well-being that are related to or affected by the presence of disease or treatment [5].

The assessment of HRQoL becomes critical in routine clinical practice, research and regulatory processes, namely in allergic and other chronic diseases. It allows a broader understanding of the impact on patients of their diseases and therapies [6,7], regardless any interpretation by physician or others [8]. However, HRQoL is rarely assessed in patients with DHR probably due to the lack of specific tools for this purpose $[4,9]$. The only specific tool measuring HRQoL in this field is the Drug Hypersensitivity Quality of Life Questionnaire (DrHy-Q) developed and validated by an Italian group [6]. The DrHy-Q was derived from a 34 generation-phase items to a 15 -items questionnaire. The purpose was to assess the specific burden of drug hypersensitivity from the patient's perspective, specifically the impact of the drug hypersensitivity in the patient's life from emotional, physical and social point of view. This questionnaire was shown to be suitable for assessing quality of life in patients that experienced a DHR and can be used alone or in combination with other patient-reported outcome questionnaires. Subsequently, the DrHy-Q was translated and validated in some cultural settings such as Spain $[9,10]$, Turkey [8], Netherlands [4] and Thailand [11], but not in Portugal or in the Portuguese language.

The main aim of this study was to translate and crosscultural validate the original Italian version of the DrHy$\mathrm{Q}$ to the Portuguese population. The secondary aims were to determine the impact of drug hypersensitivity on patients' HRQoL and to compare the clinical features between patients with confirmed versus excluded drug hypersensitivity.

\section{Methods}

We used the only validated health related quality of life questionnaire in the field of drug allergy, the Drug Hypersensitivity Quality of Life Questionnaire (DrHy-Q). It is a 15-item tool, self-completed and evaluated on a fivepoint Likert scale [from 1 (not at all) to 5 (very much)]. Higher scores signify worse HRQoL [6].

\section{Translation and cross-cultural adaptation of DrHy-Q}

The translation and cross-cultural adaptation of this HRQoL to the Portuguese language was performed according to the standards for translation and cultural adaptation for Patient-Reported Outcomes (PROs) tools $[7,12,13]$.

\section{Forward translation}

After obtaining authorization from the authors of the original instrument, the DrHy-Q [6] was translated to Portuguese language. This phase involved two local translators (Portuguese native speakers, familiar with the specific terminology and knowledgeable of the italianspeaking culture), a Portuguese HRQoL expert and a Portuguese Allergy specialist and included the following steps:

- Independently production of 2 forward versions of the questionnaire (original items, instructions and response choices), by each translator (Version $0 \mathrm{a}$ and Version $0 \mathrm{~b})$;

- Production of a single reconciled version by both translators and researchers, after discussion of the 2 forward versions (Version 1).

\section{Backward translation}

In this phase, the first reconciled forward version of the questionnaire (Version 1) was translated back into the source language by a local translator (native speaker of the target language and bilingual in source language) with no access to the original source version of the questionnaire. This backward translation, was sent to the authors in order to be compared with the original source version and detect any misunderstandings, mistranslations or inaccuracies. After the authors review and as result of this phase, a second version of the questionnaire was obtained (Version 2). Only 1 minor change was made from the first to the second version.

\section{Pilot testing}

In order to determine if the translated questionnaire is understood and the language simple and appropriate, the second version of the questionnaire was tested on a panel of 30 adult patients, through face to face interviews conducted by the same interviewer (Allergy specialist). Patients were inquired regarding any difficulty in understanding the questionnaire and their interpretation of all items was checked. This pretest phase showed that the questions were easily understandable and do not require explanation. Patients suggested only a minor change to item 2, in order to optimize the understanding. As a result of this phase, a third and final version of the translated questionnaire was produced ("Appendix"). 


\section{Validation procedures}

The psychometric properties of the Portuguese version of the DrHy-Q were evaluated in accordance with current guidelines $[14,15]$. Data was collected using a convenience sampling method [16]. A randomized group of 40 patients accepted to participate in this validation phase.

\section{Reliability}

Reliability refers to the consistency of the measure. Internal consistency and test-retest reliability were assessed.

The test-retest reliability of the DrHy-Q was evaluated by applying the questionnaire to the randomized group of 40 patients on two different occasions, one-week apart, without any intervention, personal or clinical significant changes. Questionnaires were sent by e-mail.

\section{Validity}

Validity is the degree to which an instrument measure what is intended to measure. The validity of the DrHy-Q was assessed with 3 different analyses: structural validity, divergent validity and discriminant validity.

Structural validity was assessed with exploratory factor analysis (EFA) [17]. The PGWBI instrument was chosen for the purpose of ascertaining divergent validity. It is expected a lack of correlations between PGWBI and HRQoL since theoretically they measure different constructs. The 40 randomized patients involved in the validation phase were also asked to complete the Portuguese validated version of the Psychological General Wellbeing Index (PGWBI) [18]. The PGWBI is a brief selfadministered questionnaire with 22 items on a six-point Likert scale. Each item is scored from 0 to 5 points, leading to a total score between 0 and 110 points, with higher values indicating better well-being [19]. The PGWBI evaluates six mood states (anxiety, depressed mood, positive well-being, self-control, general health, and vitality) and has been extensively used as an indicator of HRQoL in patients with chronic conditions [6-8]. Discriminant validity, the instrument's ability to differentiate between populations that are known or expected to differ [6], was evaluated by comparing DrHy-Q scores from patient groups with different clinical characteristics.

\section{Drug diagnostic work-up}

The drug hypersensitivity diagnostic work-up was performed according to international guidelines [1], in order to confirm or exclude the suspected drug hypersensitivity. The type and severity of reaction, the suspected drug and the availability of validated skin tests and in-vitro tests were considered. It included a validated questionnaire (the drug hypersensitivity questionnaire developed by European Network of Drug Allergy- ENDA) [20] and, depending on the previous referred factors, skin tests (prick, intradermal and/or patch) [21, 22], specific IgE and drug provocation test (DPT) [23].

The diagnosis of drug hypersensitivity was confirmed when skin tests were positive for validated concentrations or when specific provocation test with the suspected drug was positive. On the other hand, drug hypersensitivity diagnosis was excluded if all diagnostic procedures, including DPT with the suspected drug, were negative. Patients that did not complete the diagnostic work-up or that did not reach a conclusive diagnosis were excluded.

\section{Study population}

The final version of the translated questionnaire was applied, from July 2017 to December 2018, to 260 consecutively patients $\geq 18$ years-old, studied in our Allergy Department for suspected drug hypersensitivity. The patients filled the questionnaire in their first visit to the day hospital.

Individuals that do not completed the DrHy-Q were excluded.

Social-demographic data were also collected.

Written informed consent was obtained by all individuals included in the study and the protocol was approved by the Hospital Ethics Committee (CE-66-2016).

\section{Statistical analysis}

Data were entered and analyzed using the Statistical Package for Social Sciences version 25 and statistical significance was defined as $p<0.05$.

Variables were expressed as mean \pm standard-deviation or relative and absolute frequencies. Categories with few cases were combined.

Internal consistency of the DrHy-Q was tested by Cronbach's alpha coefficient. A value of $\geq 0.70$ is considered adequate for group comparison, but a value of 0.90 0.95 is needed for clinical application [24-26].

The test-retest reliability of the DrHy-Q was evaluated by applying the questionnaire to the randomized group of 40 patients on two different occasions, as described above. The 2 score sets were analyzed by the $t$ test for paired samples [26]. The intra-class correlation coefficient (ICC); a two-way mixed model, was also used to assess test-retest reliability [27]. This model indicates the proportion of variance that is due to between-subject variability relative to the sum of between-subject variability and measurement error. Criteria for ICC values were $<0.4$ as poor, $0.4-0.59$ as fair, $0.6-0.74$ as good and $>0.75$ as excellent reliability.

The Bland-Altman plot was also created to visualize the agreement between the questionnaire responses at the two time points (baseline and retest) [28]. 
The validity of the structure was tested using the EFA [17]. In order to evaluate the number of dimensions that emerged from the data EFA with maximum likelihood was performed. To determine the number of factors to be included eigenvalues $>1$ and the scree plot were examined. Items with factor loadings below 0.40 were planned to be eliminated.

To assess divergent validity, the Pearson correlation was used to analyze the correlation between the DHRQoL and the PGWBI total and the 6 domain scores. Values of -0.25 to 0 mean poor or no correlation; -0.50 to $-0.25=$ fair; -0.75 to $-0.50=$ moderate-to-good; -1.0 to $-0.75=$ good-to-excellent correlation.

Independent t-test or ANOVA were used to analyze differences between groups on DrHy-Q total score.

Additionally, a multiple linear regression model was designed using automatic linear modeling (ALM) [29] to evaluate which factors are associated with DrHy-Q total score. Automatic Linear Modeling is a modification and improvement of the traditional linear regression procedure, particularly in automatic variable selection and automatic data preparation [29] Multiple combinations and weighted importance are tested to determine the optimum and best-fit model possible [30]. This method also ranks predictors according to their degree of dependence from the less important to the most important.

Significant variables in the bivariate analysis were included in the model. The forward stepwise approach was used and Akaike Information Criterion Corrected (AICC) was selected as the variable entry/removal criterion. These analyses assess the discriminant validity of the DrHy-Q.

\section{Results}

\section{Study population and Drug allergy work-up}

Two hundred of patients completed the diagnostic workup and fully filled the DrHy-Q, during the study period: $78.5 \%$ were female with a mean age of $44 \pm 15$ years, range [18-77]. All data in the Additional file 1.

There were more 60 patients studied during this period that were excluded: 6 patients did not fully complete the DrHy-Q; 29 did not complete the drug allergy diagnostic work-up or did not have a conclusive result and 25 patients missed the identification number in the DrHy-Q and could not be linked to the drug diagnostic work-up. These patients were not included in any analysis.

Antibiotics were the most commonly implicated drugs (168/220 patients, $84 \%$ ), followed by Nonsteroidal Antiinflammatory drugs-NSAID (44/200 patients; $22 \%$ ). The main clinical presentations were maculopapular exanthema-MPE (39.5\%), urticaria/angioedema (22.5\%) and anaphylaxis (20\%). Fifty-one percent of the reactions were immediate and $39.5 \%$ non-immediate.

After completing the drug allergy work-up 93 patients (46.5\%) had the final diagnosis of confirmed drug allergy/ hypersensitivity.

The likelihood of confirmed drug hypersensitivity versus a negative diagnostic work-up was significantly higher in the cases involving immediate reactions $(66.3 \%$ vs $39 \%, p<0.001)$, severe reactions $(56.5 \%$ vs $1.5 \%$, $p<0.001)$, anaphylaxis $(40.0 \%$ vs $4 \%, p<0.001)$, higher number of reactions $(1.7 \%$ vs $1.3 \% p<0.001)$, higher number of suspected drugs $(1.5 \%$ vs $1.3 \% p=0.006)$, NSAID (37.6\% vs $8.4 \%, p<0.001)$, general anesthetics $(12.9$ vs 2.8 , $p=0.008)$ and an interval of time of $\leq 2$ years between reaction and study (44.0\% vs $25.0 \% p=0.027$ ).

Table 1 summarizes the socio-demographic and clinical characteristics of the patients and differences between patients with confirmed drug hypersensitivity and those with excluded drug hypersensitivity. There are some missing data mainly concerned to the socio-demographic characteristics.

\section{Validation procedures}

Thirty-one patients fully completed the questionnaires applied at the validation ( $83 \%$ were female with a mean age of $39 \pm 12$ years) (Additional file 2).

\section{Reliability}

The questionnaire's global internal consistency was 0.938 , adequate not only for group comparison but also for clinical application.

No significant differences were found between test and retest $(p=0.176)$ with a mean difference of $2.5(9.9)$ and a correlation of $0.722(p<0.001)$. The single measure of ICC was 0.713 (95\% CI 0.488-0.850) indicating good test-retest reliability. The Bland-Altman plot indicate no systematic bias (Fig. 1). Only one participant fell outside the expected limits of $\pm 2 \mathrm{SD}$ ( -17.1 to 22.0 ).

\section{Validity}

The DrHy-Q Portuguese revealed a one-dimensional structure that explained up to $54.5 \%$ of the total variance. Table 2 provides items' factor loadings. All items had a factor loading above 0.40 , therefore, none was excluded.

Concerning divergent validity, no significant correlation was found between the DrHy-Q and the PGWBI total scores $(r=-0.010 p=0.957)$. Only a fair and negative correlation was observed between DrHy-Q and the dimension general health of the PGWBI $(r=-0.490$; $p=0.006)$, but no correlation with the other 5 dimensions (Table 3). 
Table 1 Socio-demographic and clinical characteristics of patients

\begin{tabular}{|c|c|c|c|}
\hline & $\begin{array}{l}\text { Confirmed drug hypersensitivity } \\
(\mathrm{N}=93)\end{array}$ & $\begin{array}{l}\text { Excluded drug hypersensitivity } \\
(\mathrm{N}=107)\end{array}$ & $p$ value \\
\hline \multicolumn{4}{|l|}{ Gender, n (\%) } \\
\hline Female & $74(79.6)$ & $83(77.6)$ & \multirow[t]{2}{*}{0.863} \\
\hline Male & $19(20.4)$ & $24(22.4)$ & \\
\hline Age in years, Mean (SD) & $46.0(15.0)$ & $43.0(15.0)$ & 0.195 \\
\hline \multicolumn{4}{|l|}{ Academics studies, n (\%) } \\
\hline$\leq 6$ years & $4(11.4)$ & $10(24.4)$ & \multirow[t]{3}{*}{0.325} \\
\hline $7-12$ & $16(45.7)$ & $18(43.9)$ & \\
\hline$>12$ & $15(42.9)$ & $13(31.7)$ & \\
\hline \multicolumn{4}{|l|}{ Atopy, n (\%) } \\
\hline Yes & $30(33.3)$ & $28(26.7)$ & \multirow[t]{2}{*}{0.347} \\
\hline No & $60(66.7)$ & $77(73.3)$ & \\
\hline \multicolumn{4}{|l|}{ Co-morbidities, n (\%) } \\
\hline Yes & $59(63.4)$ & $58(54.7)$ & \multirow[t]{2}{*}{0.249} \\
\hline No & $34(36.6)$ & $48(45.3)$ & \\
\hline \multicolumn{4}{|l|}{ Daily medication, $\mathrm{n}(\%)$} \\
\hline Yes & $58(62.4)$ & $55(51.9)$ & \multirow[t]{2}{*}{0.153} \\
\hline No & $35(37.6)$ & $51(48.1)$ & \\
\hline \multicolumn{4}{|l|}{ Family history of drug allergy, $\mathrm{n}(\%)$} \\
\hline Yes & $5(5.5)$ & $7(6.6)$ & \multirow[t]{2}{*}{0.776} \\
\hline No & $86(94.5)$ & $99(93.4)$ & \\
\hline \multicolumn{4}{|l|}{$\Delta$ reaction- study, n (\%) } \\
\hline$\leq 2$ years & $33(44.0)$ & $23(25.0)$ & \multirow[t]{3}{*}{0.027} \\
\hline$>2$ and $\leq 5$ years & $21(28.0)$ & $29(31.5)$ & \\
\hline$>5$ years & $21(28.0)$ & $40(43.5)$ & \\
\hline \multicolumn{4}{|l|}{ Type of reaction, n (\%) } \\
\hline Immediate & $61(66.3)$ & $41(39.0)$ & \multirow[t]{3}{*}{$<0.001$} \\
\hline Non-Immediate & $24(26.1)$ & $55(52.4)$ & \\
\hline Unknown & $7(7.6)$ & $9(8.6)$ & \\
\hline \multicolumn{4}{|l|}{ Clinical manifestations, n (\%) } \\
\hline Anaphylaxis & $36(40.0)$ & $4(3.9)$ & \multirow[t]{8}{*}{$<0.001$} \\
\hline Urticaria/Angioedema & $24(26.7)$ & $21(20.6)$ & \\
\hline Maculopapular exanthema & $25(27.8)$ & $54(52.9)$ & \\
\hline Cardiovascular symptoms & $0(0.0)$ & $8(7.8)$ & \\
\hline Bronchospasm & $2(2.2)$ & $2(2.0)$ & \\
\hline Gastrointestinal symptoms & $0(0.0)$ & $3(2.9)$ & \\
\hline Fixed drug eruption & $1(1.1)$ & $2(2.0)$ & \\
\hline Unspecified general symptoms & $2(2.2)$ & $8(7.8)$ & \\
\hline \multicolumn{4}{|l|}{ Severity of reaction $n(\%)$} \\
\hline Mild & $5(21.7)$ & $142(72.1)$ & \multirow[t]{3}{*}{$<0.001$} \\
\hline Moderate & $5(21.7)$ & $52(26.4)$ & \\
\hline Severe & $13(56.5)$ & $3(1.5)$ & \\
\hline Number of reactions, Mean (SD) & $1.7(1.0)$ & $1.3(0.5)$ & $<0.001$ \\
\hline Number of suspected drugs, Mean (SD) & $1.5(0.8)$ & $1.3(0.5)$ & 0.006 \\
\hline \multicolumn{4}{|l|}{ Suspected drug, n (\%) } \\
\hline BLantibiotics & $55(59.1)$ & $78(72.9)$ & 0.051 \\
\hline Non-ßLantibiotics & $14(15.1)$ & $21(19.6)$ & 0.458 \\
\hline NSAID & $35(37.6)$ & $9(8.4)$ & $<0.001$ \\
\hline General anesthetics & $12(12.9)$ & $3(2.8)$ & 0.008 \\
\hline RCM & $9(9.7)$ & $6(5.6)$ & 0.296 \\
\hline Corticosteroids & $7(7.5)$ & $3(2.8)$ & 0.193 \\
\hline
\end{tabular}


Table 1 (continued)

\begin{tabular}{llll}
\hline & $\begin{array}{l}\text { Confirmed drug hypersensitivity } \\
(\mathbf{N}=\mathbf{9 3})\end{array}$ & $\begin{array}{l}\text { Excluded drug hypersensitivity } \\
(\mathbf{N}=107)\end{array}$ & $\boldsymbol{p}$ value \\
\hline Local anesthetics & $1(1.1)$ & $7(6.5)$ & 0.07 \\
PPI & $5(5.4)$ & $2(1.9)$ & 0.254 \\
Other & $9(9.8)$ & $3(2.8)$ & 0.069 \\
\hline
\end{tabular}

Bold values indicate statistical significance $(p<0.05)$

$S D$, standard deviation; $\Delta$ reaction- study, interval of time between reaction and study; $B L$, beta-lactam; NSAID, non- steroidal anti-inflammatory drugs; RCM, radiocontrast media; $\mathrm{PPI}$, proton pomp inhibitors

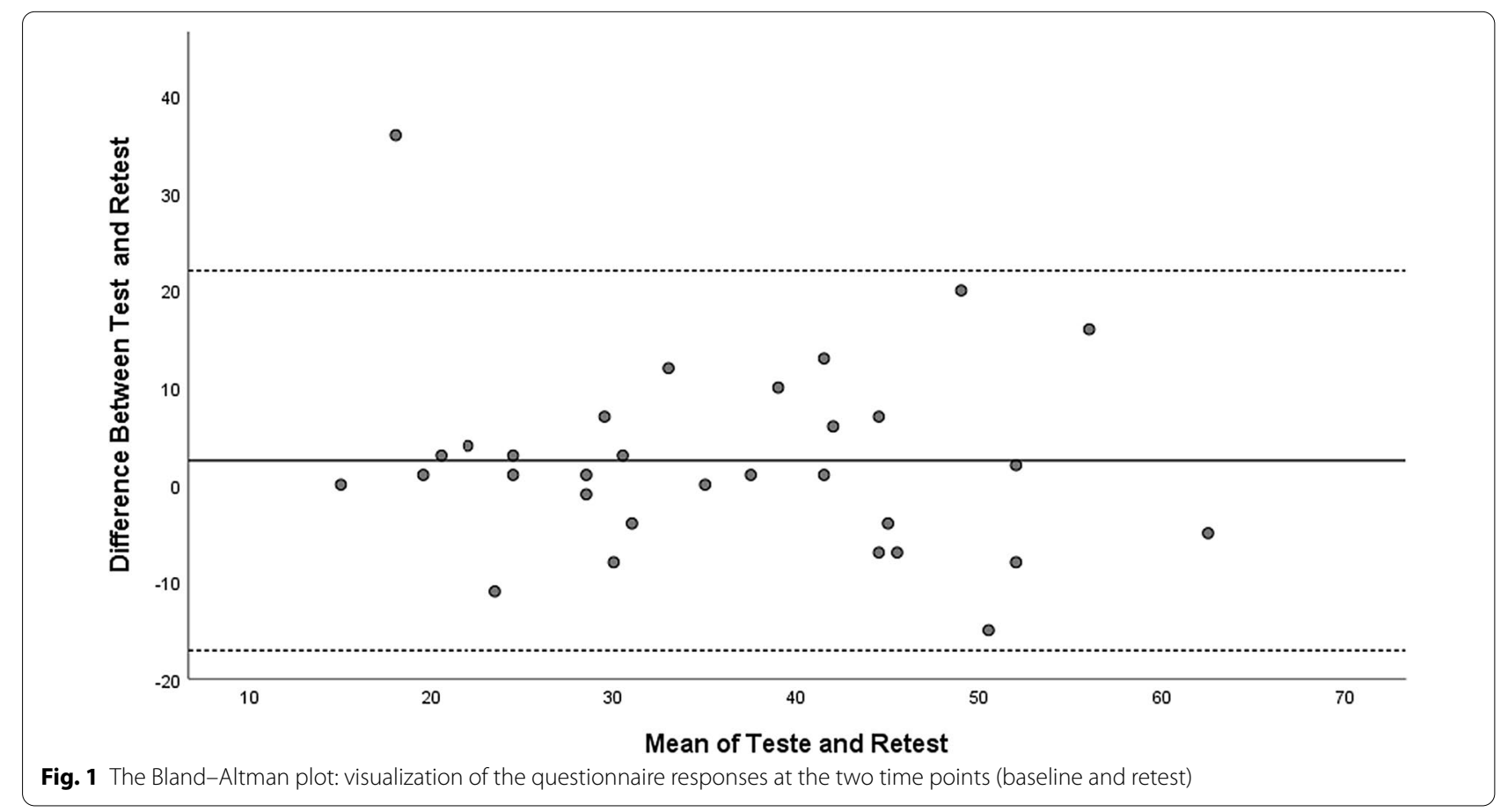

Table 2 Factor loading of each item in Portuguese version of DrHy-Q

Since I am unable to take drugs every illness limits me more than other

I am afraid of being administered a drug during an emergency to which I am allergic

I feel frightened due to my problem of allergy reaction

The problem of adverse reaction to drugs affects my life

I would like the allergist's opinion before taking drugs prescribed by other specialists

Even a little discomfort for me is a problem

The fact that I cannot use medication safely made me feel different from others

I feel anxious due to my problem of allergy reaction

For each disease I would be confident that there is a drug that I can safely take

I am afraid I could not deal with the pain

I feel anguished due to my problem of allergy reaction 
Table 3 Pearson's correlation between the DrHy-Q and the PGWBI domains

\begin{tabular}{lll}
\hline PGWBI domain & $\mathbf{r}$ & $\boldsymbol{p}$ \\
\hline Well being & -0.059 & 0.757 \\
Anxiety & -0.300 & 0.107 \\
Depression & -0.178 & 0.346 \\
Self-control & -0.131 & 0.491 \\
General health & -0.490 & $\mathbf{0 . 0 0 6}$ \\
Vitality & -0.088 & 0.644 \\
PGWBI total & -0.010 & 0.957 \\
\hline
\end{tabular}

Bold value indicates statistical significance $(p<0.05)$

DrHy-Q, Drug Hypersensitivity Quality of Life Questionnaire; PGWBI,

Psychological General Well-Being Index

\section{DrHy-Q results}

In the Table 4 are represented the results of the DrHy-Q, namely the total score according to social-demographic and clinical characteristics of patients. Mean DrHy-Q score was $36.8 \pm 12.6$ (with median 37.0; minimum: 14.0; maximum 68.0). The following factors were found to be significantly associated with higher DrHy-Q total score or impaired quality of life: older age; presence of co-morbidities; daily medication; absence of family history of drug allergy; clinical manifestations such as anaphylaxis, urticaria/angioedema or other manifestations; severe reactions; $\geq 2$ drug reactions; $\geq 2$ suspected drugs and allergy to ßL-antibiotics.

Comparing DrHy-Q scores of patients with confirmed drug allergy versus excluded drug allergy we observed significant higher values in the former group $(40.5 \pm 12.9$ vs $33.4 \pm 11.2, p<0.001)$.

Significant variables in the bivariate analysis were included in the multiple linear regression model. Two clinical factors were identified to significantly predict DrHy-Q total score: clinical manifestations and number of suspected drugs.

Patients with anaphylaxis $(\beta=11.005 ; 95 \%$ CI 5.523; 16.487), urticaria/angioedema ( $\beta=7.770 ; 95 \%$ CI 2.600; $12.940)$ and other manifestations $(\beta=7.948 ; 95 \%$ CI $1.933 ; 13.962)$ are more likely to have higher DrHy-Q total score than patients with MPE. Patients with two or more suspected drugs are more likely to have higher DrHy-Q total score $(\beta=7.927 ; 95 \%$ CI $3.687 ; 12.166)$, as shown in Table 5 . These results support the discriminant validity of the DrHy-Q.

\section{Discussion}

This study showed that the Portuguese version of DrHy$Q$ is a reliable and valid instrument for assessing HRQoL in patients with drug hypersensitivity.
Table 4 DrHy-Q total scores by socio-demographic and clinical characteristics of patients

\begin{tabular}{|c|c|c|c|c|c|}
\hline & $\mathbf{N}$ & (\%) & Mean & SD & $p$ value \\
\hline \multicolumn{6}{|l|}{ Gender } \\
\hline Female & 157 & $(78.1)$ & 36.8 & 12.3 & \multirow[t]{2}{*}{0.95} \\
\hline Male & 44 & $(21.9)$ & 36.9 & 12.7 & \\
\hline \multicolumn{6}{|l|}{ Age } \\
\hline$\leq 38$ years & 69 & $(34.3)$ & 32.4 & 10.5 & \multirow[t]{3}{*}{0.001} \\
\hline $39-51$ & 68 & $(31.8)$ & 38.1 & 13.1 & \\
\hline$>51$ & 64 & $(31.8)$ & 40.2 & 13.0 & \\
\hline \multicolumn{6}{|l|}{ Academics studies } \\
\hline$\leq 6$ years & 14 & $(18.4)$ & 41.9 & 11.5 & \multirow[t]{3}{*}{0.058} \\
\hline $7-12$ & 34 & $(44.7)$ & 33.2 & 11.7 & \\
\hline$>12$ & 28 & $(36.8)$ & 34.2 & 11.3 & \\
\hline \multicolumn{6}{|l|}{ Atopy } \\
\hline Yes & 58 & $(29.6)$ & 38.9 & 13.2 & \multirow[t]{2}{*}{0.120} \\
\hline No & 138 & $(70.4)$ & 35.9 & 12.1 & \\
\hline \multicolumn{6}{|l|}{ Co-morbidities } \\
\hline Yes & 118 & $(59.0)$ & 38.5 & 13.3 & \multirow[t]{2}{*}{0.025} \\
\hline No & 82 & $(41.0)$ & 34.4 & 11.3 & \\
\hline \multicolumn{6}{|l|}{ Daily medication } \\
\hline Yes & 114 & $(57.0)$ & 39.1 & 13.0 & \multirow[t]{2}{*}{0.002} \\
\hline No & 86 & $(43.0)$ & 33.7 & 11.4 & \\
\hline \multicolumn{6}{|c|}{ Family history of drug allergy } \\
\hline Yes & 12 & $(6.1)$ & 29.8 & 11.1 & \multirow[t]{2}{*}{0.047} \\
\hline No & 186 & $(93.9)$ & 37.2 & 12.6 & \\
\hline \multicolumn{6}{|l|}{$\Delta$ reaction- study } \\
\hline$\leq 2$ years & 56 & $(33.3)$ & 37.2 & 13.3 & \multirow[t]{3}{*}{0.216} \\
\hline 2 e 5 & 50 & $(29.8)$ & 33.4 & 7.9 & \\
\hline$>5$ & 62 & $(36.9)$ & 36.8 & 14.2 & \\
\hline \multicolumn{6}{|l|}{ Type of reaction } \\
\hline Immediate & 102 & $(51.5)$ & 38.3 & 13.5 & \multirow[t]{3}{*}{0.132} \\
\hline Non-Immediate & 80 & $(40.4)$ & 34.6 & 10.9 & \\
\hline Unknown & 16 & $(8.1)$ & 38.3 & 14.5 & \\
\hline \multicolumn{6}{|l|}{ Clinical manifestations } \\
\hline Anaphylaxis & 79 & $(40.9)$ & 41.0 & 13.4 & \multirow[t]{4}{*}{0.002} \\
\hline Urticaria/Angioedema & 40 & $(20.7)$ & 39.2 & 12.5 & \\
\hline MPE & 46 & $(23.8)$ & 32.7 & 10.2 & \\
\hline Other & 28 & $(14.5)$ & 36.9 & 13.6 & \\
\hline \multicolumn{6}{|l|}{ Severity of reaction } \\
\hline Severe & 45 & $(23.3)$ & 41.1 & 13.8 & 0.008 \\
\hline Moderate & 58 & $(30.1)$ & 36.9 & 12.1 & \\
\hline Mild & 90 & $(46.6)$ & 34.1 & 11.2 & \\
\hline Number of reactions & & & & & \\
\hline 1 & 127 & $(65.1)$ & 34.4 & 12.8 & 0.002 \\
\hline$\geq 2$ & 68 & $(34.9)$ & 40.3 & 11.1 & \\
\hline Number of suspected $d r$ & & & & & \\
\hline 1 & 140 & $(70.4)$ & 35.2 & 13.0 & 0.014 \\
\hline$\geq 2$ & 59 & $(29.6)$ & 39.9 & 10.4 & \\
\hline Class of drug & & & & & \\
\hline BL antibiotics & & & & & 0.009 \\
\hline Confirmed & 46 & (34.6) & 39.3 & 12.7 & \\
\hline
\end{tabular}


Table 4 (continued)

\begin{tabular}{llllll}
\hline & N & (\%) & Mean & SD & $p$ value \\
\hline $\begin{array}{l}\text { Excluded } \\
\text { Non-ßL antibiotics }\end{array}$ & 87 & $(65.4)$ & 33.5 & 11.8 & \\
$\quad$ Confirmed & 10 & $(28.6)$ & 41.0 & 11.6 & \\
$\quad$ Excluded & 25 & $(71.4)$ & 33.8 & 9.4 & \\
NSAID & & & & & 0.820 \\
$\quad$ Confirmed & 26 & $(65.0)$ & 42.9 & 13.1 & \\
$\quad$ Excluded & 14 & $(35.0)$ & 41.9 & 13.1 & \\
RCM & & & & & 0.324 \\
$\quad$ Confirmed & 7 & $(46.7)$ & 33.9 & 12.0 & \\
$\quad$ Excluded & 8 & $(53.3)$ & 40.4 & 12.5 & \\
\hline
\end{tabular}

Bold values indicate statistical significance $(p<0.05)$

$\mathrm{SD}$, standard deviation; MPE, Maculopapular exanthema; DH, Drug hypersensitivity

Table 5 Predictive factors of DrHy-Q total score

\begin{tabular}{llrll}
\hline Variable & B & \multicolumn{1}{c}{$\begin{array}{l}\boldsymbol{p} \\
\text { value }\end{array}$} & Cl 95\% & Importance $^{\mathbf{a}}$ \\
\hline Clinical Manifestations & & & & 0.612 \\
Anaphylaxis & 11.005 & $<0.001$ & $5.523 ; 16.487$ & \\
Urticaria/angioedema & 7.770 & 0.004 & $2.600 ; 12.940$ & \\
Other manifestations & 7.948 & 0.010 & $1.933 ; 13.962$ & \\
MPE & Ref & & & 0.388 \\
Number of drugs & & & & \\
$\geq 2$ & 7.927 & $<0.001$ & $3.687 ; 12.166$ & \\
1 & Ref & & & \\
\hline
\end{tabular}

MPE, maculopapular exanthema

${ }^{\text {a }}$ Measure of the relative importance of each predictor in estimating the model

The statistical analyses confirmed that Portuguese version of the DrHy-Q met the standards for adequate internal consistency with a Cronbach's alpha of 0.938 (Italian version 0.928) [6] along with a good test-retest reliability.

Factor analysis revealed a one-dimensional structure in line with the original Italian questionnaire ${ }^{5}$ and other translated versions $[4,8,11]$.

As expected, a negative but no significant correlation was found between the DrHy-Q and the PGWBI total scores $\mathrm{r}=-0.010 p=0.957$, since the DrHy-Q is a disease-specific questionnaire (higher scores indicating worse HRQoL) and the PGWBI is a generic quality-oflife questionnaire (higher scores indicating better wellbeing). Only a fair and negative correlation was observed between DrHy- $Q$ and the dimension general health of the PGWBI $(\mathrm{r}=-0.490 ; p=0.006)$, but no statistically significant correlation with the other 5 dimensions. These results suggest that the Portuguese DrHy-Q not only measures specific aspects of HRQoL in patients with drug hypersensitivity not assessed with generic tools, but also partially captures general aspects of HRQoL. So, these results, with slight differences with the other studies [4, $6,8,10,11]$, corroborate an adequate divergent validity. The Italian study [6] reported negative weak correlations and other studies negative fair correlations $[4,8,11]$. A negative significant correlation for the depressed mood dimension of the PGWBI questionnaire and the Spanish DrHy-Q $(r=-0.531 ; p=0.016)$ was reported, but not with other dimensions [10].

The Portuguese DrHy-Q was able to discriminate patients according to some clinical aspects. Patients with anaphylaxis, urticaria/angioedema and other manifestations are more likely to have higher DrHy-Q total score than patients with MPE. Patients with two or more suspected drugs are also more likely to have higher DrHy$\mathrm{Q}$ total score. These results are in accordance with other studies: Italian DrHy-Q also found worst HRQoL (higher scores) in patients with anaphylaxis than in patients with other milder reactions $[6,31]$ and the Dutch DrHy-Q was able to distinguish between patients with one and patients with more than one implicated drug [4]. The Turkish DrHy-Q could discriminate patients with $\geq 2$ drug hypersensitivity reactions and patients with only one reaction, and also patients with drug-induced respiratory reactions and those without respiratory reactions [8]. The Thai DrHy-Q was able to distinguish patients with or without life-threatening severe adverse cutaneous reactions (SACRs), patients with reaction to either NSAID or ßL antibiotics, or both, and patients with one or multiple implicated drug classes [11]. Our study also showed an impaired HRQoL in patients with $\geq 2$ drug hypersensitivity reactions and patients with allergy to $B \mathrm{~L}$ antibiotics, but this variable lost significance in multivariate model. As only 4 patients referred isolated respiratory symptoms they were included in the group of other manifestations. Patients with SCARs were not included since the severity of the reaction contraindicate the usual "invivo" allergy diagnostic procedures.

One of the strengths of the current study was the assessment of the potential role of socio-demographic and clinical data in the overall results DrHy-Q. We could observed how some clinical aspects of the DHR could influence the DrHy-Q scores.

Another interesting aspect of this study was the correlation between DrHy-Q scores and the final result of diagnostic work-up. Comparing DrHy-Q scores of patients with confirmed drug hypersensitivity versus excluded drug hypersensitivity we observed significant higher values in the former group. We must point out that the participants filled the questionnaire before any intervention, so they did not know any result of diagnostic work-up. These results were probably explained by the fact that some clinical variables associated with a higher 
likelihood of confirmed drug hypersensitivity were also associated with higher DrHy-Q scores.

The present study only included patients studied in the day hospital for suspected drug hypersensitivity and this is one limitation, as left out patients with severe adverse cutaneous reactions (SCARs), for instances. However, these are very rare drug hypersensitivity clinical presentations, particularly in our population.

Additionally, the majority of the patients included in this study had antibiotic and/or NSAID hypersensitivity, reflecting the global prevalence of the class of drugs involved in drug hypersensitivity, but limiting the possibility of assessing the impact of hypersensitivity to other class of drugs in patients' HRQoL.
Finally, our study design did not allow us to explore the sensitivity of DrHy-Q to changes after interventions (e.g. causal diagnosis or desensitization). In future, we intend to assess the responsiveness of the DrHy-Q to interventions trough a larger and multicenter study.

\section{Conclusions}

The Portuguese version of DrHy-Q revealed adequate validity and reliability, indicating that it is appropriate to assess the impact of drug hypersensitivity on patients' HRQoL, providing data for a better comprehension and management of our patients.

Moreover, our results highlight that the severity of the drug hypersensitivity reaction and the number of suspected drugs have impact on patient's DrHy-QoL.

\section{Appendix: Questionário}

\begin{tabular}{|c|c|c|c|c|c|c|}
\hline & & Nenhumas & Poucas & Bastantes & Muitas & Muitíssimas \\
\hline 1 & $\begin{array}{l}\text { Como não posso tomar qualquer medicamento, qualquer doença me } \\
\text { limita mais do que às outras pessoas }\end{array}$ & 1 & 2 & 3 & 4 & 5 \\
\hline 2 & $\begin{array}{l}\text { Tenho receio de que, durante uma situação urgente, me administrem } \\
\text { um medicamento ao qual sou alérgico }\end{array}$ & 1 & 2 & 3 & 4 & 5 \\
\hline 3 & $\begin{array}{l}\text { Sinto-me assustado, devido ao meu problema de alergia a medicamen- } \\
\text { tos }\end{array}$ & 1 & 2 & 3 & 4 & 5 \\
\hline 4 & O problema de alergia a medicamentos afeta a minha vida & 1 & 2 & 3 & 4 & 5 \\
\hline 5 & $\begin{array}{l}\text { Gostaria de ter a opinião de um Imunoalergologista, antes de tomar um } \\
\text { medicamento prescrito por outros especialistas }\end{array}$ & 1 & 2 & 3 & 4 & 5 \\
\hline 6 & Mesmo um pequeno desconforto é um problema para mim & 1 & 2 & 3 & 4 & 5 \\
\hline 7 & $\begin{array}{l}\text { O fato de não poder tomar tranquilamente qualquer medicamento faz- } \\
\text { me sentir diferente dos outros }\end{array}$ & 1 & 2 & 3 & 4 & 5 \\
\hline 8 & Sinto-me ansioso, devido ao meu problema de alergia a medicamentos & 1 & 2 & 3 & 4 & 5 \\
\hline 9 & $\begin{array}{l}\text { Gostaria de ter a certeza de que, para cada doença, há um medicamento } \\
\text { seguro para mim }\end{array}$ & 1 & 2 & 3 & 4 & 5 \\
\hline 10 & Tenho receio de não conseguir lidar com a dor & 1 & 2 & 3 & 4 & 5 \\
\hline 11 & $\begin{array}{l}\text { Sinto-me angustiado, devido ao meu problema de alergia a medicamen- } \\
\text { tos }\end{array}$ & 1 & 2 & 3 & 4 & 5 \\
\hline 12 & $\begin{array}{l}\text { Fico preocupado sempre que tomo um medicamento mesmo que seja } \\
\text { diferente daqueles que me causaram reação alérgica }\end{array}$ & 1 & 2 & 3 & 4 & 5 \\
\hline 13 & $\begin{array}{l}\text { Desisti de atividades de lazer (desporto, férias, viagens) devido ao meu } \\
\text { problema }\end{array}$ & 1 & 2 & 3 & 4 & 5 \\
\hline 14 & $\begin{array}{l}\text { Sinto-me com a moral em baixo, devido ao meu problema de alergia a } \\
\text { medicamentos }\end{array}$ & 1 & 2 & 3 & 4 & 5 \\
\hline 15 & A ideia de tomar um medicamento deixa-me ansioso & 1 & 2 & 3 & 4 & 5 \\
\hline
\end{tabular}




\section{Abbreviations}

DHR: Drug hypersensitivity reactions; HRQoL: Health-related quality of life; DrHy-Q: Drug Hypersensitivity Quality of Life Questionnaire; PROs: PatientReported Outcomes; ICC: Intra-class correlation coefficient; EFA: Exploratory factor analysis; PGWBI: Psychological General Well-being Index; ENDA: European Network of Drug Allergy; DPT: Drug provocation test; AICC: Akaike Information Criterion Corrected; NSAID: Nonsteroidal Anti-inflammatory drugs; ßL: Beta-lactam; RCM: Radiocontrast media; PPI: Proton pomp inhibitors; MPE: Maculopapular exanthema; SCARSs: Severe adverse cutaneous reactions.

\section{Supplementary Information}

The online version contains supplementary material available at https://doi. org/10.1186/s12955-021-01749-1.

Additional file 1: Patient database: results of the drug hypersensitivity study and DrHy-Q.

Additional file 2: Database on the validation psychometric properties of the DrHy-Q.

\section{Acknowledgements}

Not applicable.

\section{Authors' contributions}

$E D C, L R, I B$ and JRC designed the study; EDC, AMM and AC collected the data; EDC, JB, AMM, AC and LR did the data analysis; EDC, JB, AMM, AC and LR interpreted the data; EDC drafted the work and all authors revised it critically for important intellectual content. All authors read and approved the final manuscript.

\section{Funding}

Not applicable.

\section{Availability of data and materials}

Provided as a supplement to manuscript.

\section{Declarations}

\section{Ethical approval and consent to participate}

Written informed consent was obtained by all individuals included in the study and the protocol was approved by the Hospital Ethics Committee (CE-66-2016).

\section{Consent for publication}

All authors have approved the manuscript, agree with its submission to the journal and consent to its publication.

\section{Competing interests}

The authors declare that they have no conflicts of interest.

\section{Author details}

${ }^{1}$ Allergy and Clinical Immunology Department, Centro Hospitalar Universitário de S. João EPE, Porto, Portugal. ${ }^{2}$ MedInUP- Center for Drug Discover and Innovative Medicines, Faculty of Medicine, University of Porto, Porto, Portugal. ${ }^{3}$ Public Health and Forensic Sciences and Medical Education Department, Faculty of Medicine, University of Porto, Porto, Portugal. ${ }^{4}$ UNIC-Cardiovascular Research and Development Unit, University of Porto, Porto, Portugal. ${ }^{5}$ Biomedicine Department, Faculty of Medicine, University of Porto, Porto, Portugal. ${ }^{6}$ I3S- Instituto de Investigação e Inovação em Saúde, University of Porto, Porto, Portugal. ${ }^{7}$ Allergy and Respiratory Diseases Clinic - DIMI, University of Genoa, IRCCS AOU San Martino-IST, Genoa, Italy.

Received: 26 November 2020 Accepted: 17 March 2021 Published online: 10 May 2021

\section{References}

1. Demoly P, Adkinson NF, Brockow K, et al. International Consensus on drug allergy. Allergy. 2014;69:420-37.

2. Tanno LK, Torres MJ, Castells M, Demoly P, on behalf of the Joint Allergy Academies. What can we learn in drug allergy management from World Health Organization's international classifications? Allergy. 2018;73:987-92.

3. Dias de Castro E, Carolino F, Ribeiro L, Cernadas JR. Overview of drug allergy: From immunogenetic basis to practice. Acta Med Port. 2018;31(10):581-8.

4. Moayeri M, Van Os-Medendorp H, Baiardini I, Rockmann H. Assessment of validity and reliability of Drug Hypersensitivity Quality of Life Questionnaire: the Dutch experience. Eur Ann Allergy Clin Immunol. 2017:49(3):129-34

5. Ebrahim S. Clinical and public health perspectives and applications of health-related quality of life measurement. Soc Sci Med. 1995;41:1383-94.

6. Baiardini I, Braido F, Fassio O, Calia R, Canonica GW, Romano A, DrHy-Q PROs Italian Group. Development and validation of the Drug Hypersensitivity Quality of Life Questionnaire. Ann Allergy Asthma Immunol. 2011;106(4):330-5.

7. Baiardini I, Bousquet PJ, Brzoza Z, et al. Recommendations for assessing Patient-Reported Outcomes and Health-Related quality of life in clinical trials on allergy: a GA² LEN taskforce position paper. Allergy. 2010;65:290-5.

8. Bavbek S, Ozdemir SK, Erdogan BD, et al. Turkish version of the Drug Hypersensitivity Quality of Life Questionnaire: assessment of reliability and validity. Qual Life Res. 2016;25:101-9.

9. Gastaminza G, Herdman M, Baiardini I, Braido F, Corominas M. Crosscultural adaptation and linguistic validation of the Spanish version of the drug hypersensitivity quality of life questionnaire. J Investig Allergol Clin Immunol. 2013;23(7):504-21.

10. Gastaminza G, Ruiz-Canela M, Baiardini I, Andrés-López B, Corominas M. Psychometric validation of the Spanish Version of the DHRQoL Questionnaire. J Investig Allergol Clin Immunol. 2016;26:322-3.

11. Chongpison $Y$, Rerknimitr $P$, Hurst $C$, et al. Reliability and validity of the Thai Drug Hypersensitivity Quality of Life Questionnaire: a multi-center study. Int J Qual Health Care. 2019;31:527-34.

12. Beaton D, Bombardier C, Guilemin F, Ferraz MB. Guidelines for the process of cross-cultural adaptation of self-report measures. Spine. 2000;25(24):3186-91.

13. Wild D, Grove A, Martin M, et al. Principles of good practice for the translation and cultural adaptation process for patient-reported outcomes (PRO) measures: report of the ISPOR task force for translation and cultural adaptation. Value Health. 2005;8(2):94-104.

14. Testa MA, Simonson DC. Assessment of quality-of-life outcomes. NEJM. 1996:334:835-40.

15. Frost MH, Reeve BB, Liepa AM, Stauffer JW, Hays RD, Mayo/FDA PatientsReported Outcomes Consensus Meeting Group. What is sufficient evidence for the reliability and validity of patient-reported outcomes measures? Value Health. 2007;10(Suppl2):S94-105.

16. MacCallum RC, Browne MW, Sugawara HM. Power analysis and determination of sample size for covariance structure modeling. Psychol Methods. 1996:1:130-49.

17. Hu LT, Bentler PM. Cutoff criteria for fit indexes in covariance structure analysis: conventional criteria versus new alternatives. Struct Equ Model. 1999;6(1):1-55.

18. Leite A, Ramires A, Moura A, et al. Psychological well-being and health perception: predictors for past, present and future. Arch Clin Psychiatry. 2019:46(3):53-60.

19. Dupuy HJ. The psychological general well-being (PGWB) index. In: Wenger NK, Matson MI, Furberg CD, Elinson J, editors. Assessment of quality of life in clinical trials of cardiovascular therapies. New York: Le Jacq Publishing Inc; 1984. p. 170-83.

20. Demoly P, Kropf R, Bircher A, Pichler WJ. for EAACl interest group on drug hypersensitivity. Drug hypersensitivity questionnaire. Allergy. 1999;54:999-1003. 
21. Brockow K, Romano A, Blanca M, Ring J, Pichler W, Demoly P. General considerations for skin test procedures in the diagnosis of drug hypersensitivity. Allergy. 2002;57:45-51.

22. Brokow K, Garvey LH, Aberer W, et al. Skin test concentrations for systemically administered drugs- an ENDA-EAACI Drug Allergy Interest Group position paper. Allergy. 2013;68:702-12.

23. Aberer W, Bircher A. Romano et al for ENDA and the EAACl interest group on drug hypersensitivity. Drug provocation testing in the diagnosis of drug hypersensitivity reactions. Allergy. 2003;58:854-63.

24. Cronbach LJ. Coefficient alpha and the internal structure of tests. Psychometrika. 1951;16(3):297-334

25. Bland JM, Altman DG. Statistics notes: Cronbach's alpha. Br Med J. 1997:314:572.

26. Altman DG. Practical Statistics for Medical Research. London: Chapman and Hall; 2001.

27. Fleiss JL, Levin B, Paik MC. Statistical methods for rates and proportions. Hoboken: Wiley; 2003.
28. Bland JM, Altman DG. Statistical methods for assessing agreement between two methods of clinical measurement. Lancet. 1986;1:307-10

29. Yang $\mathrm{H}$. The case for being automatic: introducing the automatic linear modeling (LINEAR) procedure in SPSS statistics. Multiple Linear Regression Viewpoints. 2013;39(2):27-37.

30. Akaike H. Information theory and an extension of the maximum likelihood principle. In: Proceedings of the second international symposium on information theory 1973, 267-281.

31. Baiardini I, Gaeta F, Molinengo G, Canonica GW, Romano A. Qualityof-life issues in survivors to anaphylactic reactions to drugs. Allergy. 2015;70:877-9.

\section{Publisher's Note}

Springer Nature remains neutral with regard to jurisdictional claims in published maps and institutional affiliations.
Ready to submit your research? Choose BMC and benefit from:

- fast, convenient online submission

- thorough peer review by experienced researchers in your field

- rapid publication on acceptance

- support for research data, including large and complex data types

- gold Open Access which fosters wider collaboration and increased citations

- maximum visibility for your research: over $100 \mathrm{M}$ website views per year

At $\mathrm{BMC}$, research is always in progress.

Learn more biomedcentral.com/submissions 